\title{
レーザー駆動中性子源の特徵
}

\author{
森 芳孝 ${ }^{1}$, 安部 勇輝 ${ }^{2}$, 田中 浩基 ${ }^{3}$, 花山 良平 ${ }^{1}$, 鬼柳 善明 ${ }^{4}$, 長友 ${\text { 英夫 }{ }^{2} \text {, 砂原 淳 }}^{5}$ \\ '光産業創成大学院大学 ( ₹431-1202 静岡県浜松市西区吳松町1955-1) \\ ${ }^{2}$ 大阪大学 レーザー科学研究所 (⿳565-0871 大阪府吹田市山田丘2-6) \\ 3 京都大学 複合原子力科学研究所 ( $=590-0494$ 大阪府泉南郡熊取町朝代西2) \\ 4名古屋大学 工学研究科 ( $7464-8602$ 愛知県名古屋市千種区不老町) \\ 5パデュー大学 極限環境物質センター(500 Centra Dr. West Lafayette, Indiana, 47907)
}

\section{Characteristics of Laser-Driven Neutron Sources}

\author{
Yoshitaka MORI, ${ }^{1}$ Yuki ABE, ${ }^{2}$ Hiroki TANAKA, ${ }^{3}$ Ryohei HANAYAMA, ${ }^{1}$ \\ Yoshiaki KIYANAGI, ${ }^{4}$ Hideo NAGATOMO, ${ }^{2}$ and Atsushi SUNAHARA ${ }^{5}$ \\ ${ }^{1}$ The Graduate School for the Creation of New Photonics Industries, 1955-1 Kurematsu-cho, Nishi-ku, Hamamatsu, Shizuoka 431-1202 \\ ${ }^{2}$ Institute of Laser Engineering, Osaka University, 2-6 Yamadaoka, Suita, Osaka 565-0871 \\ ${ }^{3}$ Institute for Integrated Radiation and Nuclear Science, Kyoto University, 2 Asashiro-Nishi, Kumatori-cho, Sennan-gun, Osaka 590-0494 \\ ${ }^{4}$ Graduate School of Engineering, Nagoya University, Furocho, Chikusa-ku, Nagoya, Aichi 464-8602 \\ ${ }^{5}$ Center for Materials Under Extreme Environment (CMUXE), Purdue University, 500 Central Dr. West Lafayette, Indiana, 47907
}

(Received June 18, 2018)

\begin{abstract}
Laser-driven neutron sources offer a unique characteristic as a brightness neutron source because they provide a short pulse duration (less than $\mathrm{ns}$ ) in time and a small spot size (a few $\mathrm{mm}^{2}$ ) in space at the source point. The peak flux per driver energy reaches $10^{17} \mathrm{n} / \mathrm{cm}^{2} / \mathrm{s} / \mathrm{J}$, which is 1,000 times higher than that achieved by an accelerator-driven source. We compared the characteristics of a laser-driven neutron source with those achieved by an accelerator-driven source by focusing on the amount of neutron production numbers on the source as a function of driver energy. We also present the technological status or perspective of laser-driven neutron sources in order to achieve an average production rate $10^{11} \mathrm{n} / \mathrm{sr} / \mathrm{sec}$ that obtained by a compact accelerator-driven neutron source.
\end{abstract}

Key Words: Laser driven neutron sources, Accelerator driven neutron source, High-power laser, Ultraintense laser

\section{1. はじめに}

超高強度レーザーによるレーザー駆動量子ビーム発生 は, 電子加速 ${ }^{1)}$, イオン加速 ${ }^{2}$, 及び中性子発生 ${ }^{3,4)}$ 等に 展開されてきた。レーザー駆動量子ビームの研究 は, 2000年代初頭の「原理実証」を経て, 最近は, 「応用 展開」を意識している。レーザー駆動量子ビームを，学 術あるいは産業分野へ展開していくためには, 既存ない し既設量子ビーム源との共創が望ましい.

量子ビームの一種である中性子線は, 高い透過力や軽 元素の識別能力などの特徵を有するため, 産業利用の分 野等における分析・解析ツールとしての検討がなされて いる.レーザー駆動中性子源は, 既存の加速器駆動と比 ベ, 短パルス (1 ns以下), 点光源 (10 mm以下)の特徵を 有する。 その結果, 中性子発生点におけるピークフラッ クスで比較すると，レーザー中性子源の特性が際立つ。 一方, 平均中性子発生率は, 加速器駆動と比べ 3 桁以上
低い，その克服には，高平均パルスレーザードライバー 開発が必要である。

本解説では，コンパクト中性子源として期待される2 つの方式: 加速器駆動型, 及びレーザー駆動型を比較 し，レーザー駆動型の特徴を明らかにする。またレー ザー駆動型中性子源を構成する要素技術の現状について 紹介する。

\section{2. 加速器駆動型とレーザー駆動型の中性子源比較}

レーザー駆動中性子源は, 加速器駆動と比べ, 短パル ス (1 ns以下), 点光源 (10 mm以下)の特徵を有する. Fig. 1 にレーザー駆動及び加速器駆動中性子源の比較を 示す。レーザー駆動型では，まず，レーザー光を照射 ターゲットへ集光し, ターゲットをプラズマ化する。そ の結果, レーザー照射領域に, 局所瞬間的に高エネル ギー密度状態が形成され, 電子, ガンマ線, イオン, 中 


\begin{tabular}{|c|c|c|}
\hline & Laser-driven & Accelerator-driven \\
\hline Pulse duration & $<$ ns & $\sim \mu \mathrm{S}$ \\
\hline Source size & $0.1 \sim 10 \mathrm{~mm}$ & $\sim 10 \mathrm{~cm}$ \\
\hline Generation efficiency & $\sim 10^{4-8} \mathrm{n} / \mathrm{sr} / \mathrm{J}$ & $\sim 10^{8} \mathrm{n} / \mathrm{sr} / \mathrm{J}$ \\
\hline Peak flux & $>10^{17} \mathrm{n} / \mathrm{cm}^{2} / \mathrm{sec} / \mathrm{J}$ & $\sim 10^{14} \mathrm{n} / \mathrm{cm}^{2} / \mathrm{sec} / \mathrm{J}$ \\
\hline Repetition & Single shot, $<1 \mathrm{~Hz}$ & $\begin{array}{l}\text { Single Shot, } \\
20-200 \mathrm{~Hz}\end{array}$ \\
\hline $\begin{array}{l}\text { Configuration } \\
\text { at the source }\end{array}$ & 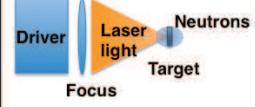 & Driver $\begin{array}{c}\text { Particle } \\
\text { beam }\end{array}$ \\
\hline
\end{tabular}

Fig. 1 Specifications of pulse neutron source for laser driven and accelerator driven.

性子などの量子ビームが発生する，特に，パルス幅が数 ピコ秒以下の超高強度レーザーを用いる場合は，照射 ターゲットからエネルギー $\mathrm{MeV}$ 級の荷電粒子ビームが 発生する ${ }^{5)}$ 。これら荷電粒子ビームを, レーザー伝搬軸 後方に設置した中性子発生ターゲットへ当てることで中 性子が発生する。この方式を, 照射ターゲットをピッ チャー, 中性子発生ターゲットをキャッチャーになぞら え, ピッチャーキャッチャー方式と呼ぶ. 荷電粒子発生 に扔いて，レーザー照射強度を極限まで引き上げ，レー ザー光と物質との非線形な相対論効果を励起すること で, 荷電粒子の高エネルギー化及び発生量の向上が試み られている6 . ピッチャーキャッチャー方式によるレー ザー駆動中性子発生の進展は, 余語らにより解説され $3^{7)}$.

一方, 加速器駆動型では, 線形加速器などで加速され た荷電粒子を, 中性子発生ターゲットへ入射し, 核反応 により中性子を発生させる。荷電粒子のエネルギーは加 速器の性能で決定され, 中性子発生に対して, 核反応断 面積を考慮した中性子発生ターゲット厚み等の最適化が 行われる, 中性子発生量は, 荷電粒子の電荷数に線形的 に比例する, 荷電粒子のビーム径は, 加速ビームの空間 電荷効果による制限を受ける

加速器駆動型およびレーザー駆動型において, 荷電粒

(a)

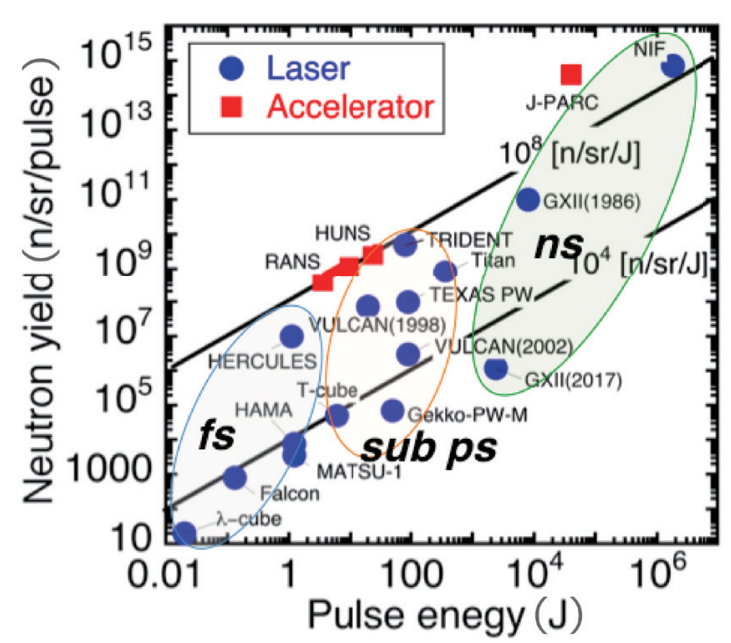

子エネルギー及びレーザーパルスエネルギーをドライ バーエネルギーと定め, 性能比較をおこなった. 加速器 駆動中性子源は, 大型陽子加速器J-PARC核破砕中性子 源 ${ }^{8-13)}$, 理研の小型陽子加速器中性子源RANS ${ }^{15)}$, 及び北 大の電子加速器中性子源HUNS ${ }^{16-18)}$ を取り上げた. Table 1 に, 各々の加速器駆動中性子源の荷電粒子ドラ イバ及び発生中性子性能をまとめた。尚, HUNSについ ては, 現在ハイパワー化のためのリプレースを行って掠 り，2018年中には新加速器の運転が行われる予定であ る、レーザー駆動型に扔いては，フェムト秒チタンサ ファイアレーザー19-23)，サブピコ及びピコ秒ガラスレー ザー24-30)を用いたビーム核融合反応等による中性子発 生，及び，ナノ秒ガラスレーザー31-33)を用いた熱核融合 による中性子発生を取り上げた，Table 2 に，代表的な レーザー駆動中性子源のレーザードライバ及び発生中性 子性能をまとめた，尚，米国国立点火施設(National Ignition Facility: NIF) について, 最近, 世界最高值の核融 合発生中性子数 $1.9 \times 10^{16} \mathrm{n} /$ pulseが報告され, 研究開発が 進展している34. Fig. 2 に，ドライバーエネルギーに対 する(a)パルスあたりの中性子発生量, 及び(b) 時間平均 した際の中性子発生量を示す。性子発生量は単位立体 角当たりとした，加速器駆動については，発生点からの 等方散乱を仮定した，中性子を駆動するドライバーエネ ルギーを統一単位とすることで, 両者の特性比較が可能 となる。

現状のレーザー駆動中性子源は, 加速器駆動型と比較 した際，パルス当たりの発生中性子量は同等量が達成さ れているが，時間平均すると差が顕著となる，例え ば, Fig. 2(a)に示す様に, 米国国立点火施設 (NIF) で得られた中性子発生数は, パルス当たりJ-PARC相当 $\left(1 \times 10^{15} \mathrm{n} / \mathrm{sr} / \mathrm{pulse}\right)$ が達成されている。このことは，1パ ルスでのデー夕取得が可能な応用であれば，すでにレー ザー駆動中性子源は応用可能な中性子量が達成されてい ることを意味している。, 一方, Fig. 2(b)より, 時間平均 で比較すると5桁以上発生量が低下する。

(b)

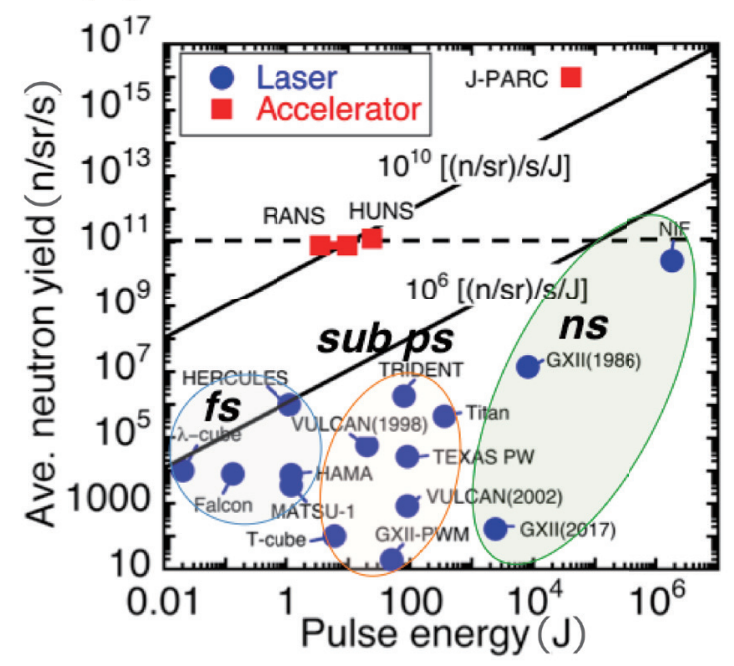

Fig. 2 Neutron yields (a) per pulse and (b) per sec in rela- tion to driver energy. 
Table 1 Specification of accelerator-driven-neutron sources.

\begin{tabular}{|c|c|c|c|}
\hline Facility & $\mathrm{J}_{-P A R C}{ }^{8-14)}$ & RANS $^{15)}$ & HUNS $^{16-18)}$ \\
\hline \multicolumn{4}{|l|}{ Accelerated beam parameters } \\
\hline Charged particle & Proton & Proton & Electron \\
\hline Average beam power & $1 \mathrm{MW}$ & $0.7 \mathrm{~kW}$ & $1.2 \mathrm{~kW}$ \\
\hline Peak beam power & $40 \mathrm{GW}$ & $54 \mathrm{~kW}$ & 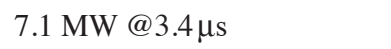 \\
\hline Particle energy & $3 \mathrm{GeV}$ & $7 \mathrm{MeV}$ & $35 \mathrm{MeV}(\max .45 \mathrm{MeV})$ \\
\hline Repetition & $25 \mathrm{~Hz}$ & $14-200 \mathrm{~Hz}$ & Single $-200 \mathrm{~Hz}$ \\
\hline \multirow[t]{2}{*}{ Beam energy per pulse } & $40 \mathrm{~kJ}$ & $9.7 \mathrm{~J} @ 72.2 \mathrm{~Hz}$ & $0.25 \mathrm{~J} @ 50 \mathrm{~Hz}, 10 \mathrm{~ns}$ \\
\hline & & $3.5 \mathrm{~J} @ 200 \mathrm{~Hz}$ & $24 \mathrm{~J} @ 50 \mathrm{~Hz}, 3.4 \mu \mathrm{s}$ \\
\hline Average current & $333 \mu \mathrm{A}$ & $100 \mu \mathrm{A}(\max )$. & $36 \mu \mathrm{A} @ 50 \mathrm{~Hz}, 3.4 \mu \mathrm{s}$ \\
\hline Charge per pulse & $13.3 \mu \mathrm{C}$ & $1.39 \mu \mathrm{C} @ 72.2 \mathrm{~Hz}$ & $0.72 \mu \mathrm{C} @ 50 \mathrm{~Hz}, 3.4 \mu \mathrm{s}$ \\
\hline \multirow[t]{2}{*}{ Pulse duration } & $1 \mu \mathrm{s}$ & $8-180 \mu \mathrm{s}$ & $0.01-3.4 \mu \mathrm{s}$ \\
\hline & $0.1 \mu \mathrm{s}$ (s-bunch) & & \\
\hline Duty ratio & $0.0025 \%$ & $<1.3 \%$ & $<0.017 \%$ \\
\hline \multirow[t]{2}{*}{ Beam current per pulse } & $13.3 \mathrm{~A}$ & 7.7 mA @180 $\mu \mathrm{s}$ & $0.212 \mathrm{~A} @ 3.4 \mu \mathrm{s}$ \\
\hline & $67 \mathrm{~A}$ (s-bunch) & & 0.75 A@10ns \\
\hline Projected area of beam & $150 \times 70 \mathrm{~mm}^{2}$ & $\phi 20 \mathrm{~mm}$ & $\phi 12 \mathrm{~mm}$ \\
\hline \multicolumn{4}{|l|}{ Neutron generation } \\
\hline Target material & Mercury & Beryllium & Tungsten+Lead+Lead \\
\hline Size (width $\times$ hight, thickness) & $500 \times 130 \mathrm{~mm}^{2}, 900 \mathrm{~mm}$ & $\phi 50 \mathrm{~mm}, 0.3 \mathrm{~mm}$ & $\mathrm{~W}: \phi 60 \mathrm{~mm}, 1.5 \mathrm{~mm}$ \\
\hline & & & $\mathrm{Pb}: 67 \times 67 \mathrm{~mm}^{2}, 19+24 \mathrm{~mm}$ \\
\hline Neutron generation scheme & Spallation & $\mathrm{Be}(\mathrm{p}, \mathrm{n})$ & Photonuclear reaction: $(\gamma, \mathrm{n})$ \\
\hline \multicolumn{4}{|l|}{ Neutron parameters at source } \\
\hline \multirow[t]{2}{*}{ Produced numbers per pulse } & $5 \times 10^{15} \mathrm{n} /$ pulse & $1.4 \times 10^{10} \mathrm{n} /$ pulse @72 Hz & $3.2 \times 10^{10} \mathrm{n} /$ pulse @ $50 \mathrm{~Hz}$ \\
\hline & $2.5 \times 10^{15} \mathrm{n} /$ pulse (s-bunch) & $0.5 \times 10^{10} \mathrm{n} /$ pulse @200 Hz & \\
\hline Average production rate & $1.3 \times 10^{17} \mathrm{n} / \mathrm{sec}$ & $1 \times 10^{12} \mathrm{n} / \mathrm{sec}$ & $1.6 \times 10^{12} \mathrm{n} / \mathrm{sec} @ 1 \mathrm{~kW}$ \\
\hline \multirow[t]{2}{*}{ Peak production rate } & $5 \times 10^{21} \mathrm{n} / \mathrm{sec}$ & $7.8 \times 10^{13} \mathrm{n} / \mathrm{sec}$ & $9.4 \times 10^{15} \mathrm{n} / \mathrm{sec} @ 3.4 \mu \mathrm{s}$ \\
\hline & $2.5 \times 10^{22} \mathrm{n} / \mathrm{sec}(\mathrm{s}-$ bunch $)$ & & $3.3 \times 10^{16} \mathrm{n} / \mathrm{sec} @ 10 \mathrm{~ns}$ \\
\hline \multirow[t]{2}{*}{ Peak flux (estimated) } & $1.2 \times 10^{18} \mathrm{n} / \mathrm{cm}^{2} / \mathrm{s}$ & $1.2 \times 10^{13} \mathrm{n} / \mathrm{cm}^{2} / \mathrm{s}$ & $8.3 \times 10^{14} \mathrm{n} / \mathrm{cm}^{2} / \mathrm{s} @ 3.4 \mu \mathrm{s}$ \\
\hline & $6 \times 1018 \mathrm{n} / \mathrm{cm}^{2} / \mathrm{s}$ (s-bunch) & & $2.9 \times 10^{15} \mathrm{n} / \mathrm{cm}^{2} / \mathrm{s} @ 10 \mathrm{~ns}$ \\
\hline Accelerator type & Linac + High-rep. synchrotron & Linac & Linac \\
\hline Facility size & Large-scale user facility & Academic laboratory size & Academic laboratory size \\
\hline
\end{tabular}

s-bunch: single-bunch, High-rep.: High-repetition

時間平均の発生量が低いのは, レーザードライバーの 平均出力が低いためである。加速器駆動と比較すると, パルス当たりのドライバーエネルギーは加速器と同等以 上を達成しているが, 繰り返し及び平均出力に隔たりが ある. Fig. 3 に, 加速器駆動とレーザー駆動におけるド ライバーエネルギーに対するドライバーの繰り返しの関 係を示す。RANSを例にあげると, 繰り返し $72 \mathrm{~Hz}$, 陽 子エネルギー $10 \mathrm{~J} て ゙$ 運用されており, 平均出力は $1 \mathrm{~kW}$ 程 度である。一方, TRIDENTレーザーでは, パルスエネ ルギー $80 \mathrm{~J}$, ショット間隔は 1 時間で, 平均出力は $1 \mathrm{~W}$ 以 下である。レーザー駆動中性子発生に用いられたレー ザーシステムの大半は, 平均出力 $1 \mathrm{~W}$ 以下である.

RANS相当の平均中性子発生率 $\left(10^{11} \mathrm{n} / \mathrm{sr} / \mathrm{s}\right)$ を, レー ザー駆動で定常的に実現するためには，レーザースペッ
ク $(100 \mathrm{~J} / 100 \mathrm{~Hz})$ を視野にいれた高平均出力高強度レー ザー開発が求められる。 Fig. 2(b)より, レーザー駆動 で, 平均中性子発生率：10 $11 \mathrm{n} / \mathrm{sr} / \mathrm{s}$ を定常的に発生さ せるためには，以下3つの方法が考えられる。第1 は，ジュール級フェムト秒レーザー(HERUCULES: $1 \mathrm{~J} / 40 \mathrm{fs} / 0.1 \mathrm{~Hz}, 1 \times 10^{6} \mathrm{n} / \mathrm{sr} / \mathrm{s} の 10 \mathrm{kHz}$ 運用である。第2 は, 100 ジュール級サブピコ秒レーザー(TRIDENT: $80 \mathrm{~J} / 0.6 \mathrm{ps} / 0.00037 \mathrm{~Hz}, \quad 1.9 \times 10^{6} \mathrm{n} / \mathrm{sr} / \mathrm{s}$ の $20 \mathrm{~Hz}$ 運用である. 第3は, 10 キロジュール級ナノ秒レーザー (GXII: $8 \mathrm{~kJ} / 0.75 \mathrm{~ns} / 0.00014 \mathrm{~Hz}, 1.4 \times 10^{7} \mathrm{n} / \mathrm{sr} / \mathrm{s}$ の $1 \mathrm{~Hz}$ 運用であ る。それぞれの中性子発生機構は，第 1 及び第2は，ピッ チャーキャッチャー方式によるビーム核融合，第3は， 爆縮方式による熱核融合である。ここで，Fig. 2(a)をみ ると, 現時点において, ピッチャーキャッチャー方式に 
Table 2 Specification of laser-driven-neutron sources.

\begin{tabular}{|c|c|c|c|c|c|c|c|c|c|}
\hline Laser system & $\lambda$-cube & $\begin{array}{l}\text { MAT- } \\
\text { SU-1 }\end{array}$ & $\begin{array}{c}\text { HERCU- } \\
\text { LES }\end{array}$ & HAMA & $\begin{array}{c}\text { TRI- } \\
\text { DENT }\end{array}$ & TexasPW & GXII & GXII & NIF \\
\hline \multicolumn{10}{|l|}{ Laser spec. } \\
\hline On-target energy & $20 \mathrm{~mJ}$ & $1.2 \mathrm{~J}$ & $1.1 \mathrm{~J}$ & $1.2 \mathrm{~J}$ & $80 \mathrm{~J}$ & $90 \mathrm{~J}$ & $2.4 \mathrm{~kJ}$ & $8 \mathrm{~kJ}$ & $1.9 \mathrm{MJ}$ \\
\hline Pulse duration & $35 \mathrm{fs}$ & $60 \mathrm{fs}$ & $40 \mathrm{fs}$ & $104 \mathrm{fs}$ & $0.6 \mathrm{ps}$ & $0.15 \mathrm{ps}$ & $0.1 \mathrm{~ns}$ & $0.75 \mathrm{~ns}$ & $20 \mathrm{~ns}$ \\
\hline Peak power & $0.6 \mathrm{TW}$ & $20 \mathrm{TW}$ & $28 \mathrm{TW}$ & $12 \mathrm{TW}$ & $133 \mathrm{TW}$ & $0.6 \mathrm{PW}$ & $24 \mathrm{TW}$ & $11 \mathrm{TW}$ & $425 \mathrm{TW}$ \\
\hline Focal spot size & $1.3 \mu \mathrm{m}$ & $8 \mu \mathrm{m}$ & $1.3 \mu \mathrm{m}$ & $13 \mu \mathrm{m}$ & $4 \mu \mathrm{m} *$ & $10 \mu \mathrm{m}$ & $200 \mu \mathrm{m}$ & $790 \mu \mathrm{m}$ & \\
\hline Intensity $\left(\mathrm{W} / \mathrm{cm}^{2}\right)$ & $3 \times 10^{19}$ & $3 \times 10^{18}$ & $2 \times 10^{21}$ & $4.7 \times 10^{18}$ & $1 \times 10^{21 *}$ & $8 \times 10^{20 *}$ & $7.6 \times 10^{16}$ & $1.8 \times 10^{14}$ & \\
\hline Repetition & $500 \mathrm{~Hz}$ & $1 \mathrm{~Hz}$ & $0.1 \mathrm{~Hz}$ & $1 \mathrm{~Hz}$ & $1 \mathrm{shot} / \mathrm{h}$ & $1 \mathrm{shot} / \mathrm{h}$ & $1 \mathrm{shot} / 2 \mathrm{~h}$ & $1 \mathrm{shot} / 2 \mathrm{~h}$ & $1 \mathrm{shot} / 8 \mathrm{~h}$ \\
\hline \multicolumn{10}{|l|}{ Neutron gen. } \\
\hline Target & $\begin{array}{l}\mathrm{D}_{2} \mathrm{O} \\
\text { water }\end{array}$ & $\begin{array}{l}\text { CD nano-ptcl. } \\
\text { + CD sheet }\end{array}$ & $\begin{array}{l}\mathrm{CH}_{2} \text { foil } \\
+\mathrm{LiF} \text { blk. }\end{array}$ & $\mathrm{CD}$ beads & $\begin{array}{l}\mathrm{CD}_{2} \text { foil } \\
+ \text { Be blk. }\end{array}$ & $\begin{array}{l}\mathrm{CH} \text { foil } \\
+\mathrm{Cu} \text { stack }\end{array}$ & $\begin{array}{l}\text { cone-in } \\
\mathrm{CD} \text { shell }\end{array}$ & $\begin{array}{l}\mathrm{SiO}_{2} \text { caps. } \\
\text { w/ DT gas }\end{array}$ & $\begin{array}{l}\text { Hohlraum } \\
\text { w/ DT ice }\end{array}$ \\
\hline Reaction & $\mathrm{D}(\mathrm{d}, \mathrm{n})$ & $\mathrm{D}(\mathrm{d}, \mathrm{n})$ & $\operatorname{Li}(p, n)$ & $\mathrm{D}(\mathrm{d}, \mathrm{n})$ & $\mathrm{Be}(\mathrm{d}, \mathrm{n})$ & $\mathrm{Cu}(\gamma, \mathrm{n})$ & DD (th.) & DT (th.) & DT (th.) \\
\hline \multicolumn{10}{|l|}{ Neutron spec. } \\
\hline Prod. numbers (n/sr) & $2 \times 10^{1}$ & $3.6 \times 10^{3}$ & $1.0 \times 10^{7}$ & $7.6 \times 10^{3}$ & $5 \times 10^{9}$ & $9.5 \times 10^{6}$ & $1.2 \times 10^{6}$ & $1.0 \times 10^{11}$ & $7.2 \times 10^{14}$ \\
\hline Duration & $3 \mathrm{ps}^{*}$ & $10 \mathrm{ps}^{*}$ & $50 \mathrm{ps}^{*}$ & $>0.1 \mathrm{~ns}^{*}$ & $0.3 \mathrm{~ns}^{*}$ & $50 \mathrm{ps}$ & $50 \mathrm{ps}$ & $<100 \mathrm{ps}$ & $152 \mathrm{ps}$ \\
\hline \multirow[t]{2}{*}{ Source size } & $\phi 10 \mu \mathrm{m}$ & $\phi 40 \mathrm{~mm}$ & $\phi 10 \mathrm{~mm} *$ & $\phi 1 \mathrm{~mm}$ & $\phi 6 \mathrm{~mm}$ & $\phi 26 \mathrm{~mm}$ & $\phi 100 \mu \mathrm{m}$ & $\phi 200 \mu \mathrm{m}$ & $\phi 73 \mu \mathrm{m}$ \\
\hline & & $\mathrm{L} 40 \mathrm{~mm} *$ & & & L12 mm & $\mathrm{L} 18 \mathrm{~mm}$ & & & \\
\hline Ave. prod. ratio $(\mathrm{n} / \mathrm{s})$ & $1.3 \times 10^{5}$ & $4.5 \times 10^{4}$ & $1.3 \times 10^{7}$ & $9.6 \times 10^{4}$ & $1.7 \times 10^{7}$ & $3.3 \times 10^{5}$ & $2.1 \times 10^{3}$ & $1.7 \times 10^{8}$ & $2.1 \times 10^{11}$ \\
\hline Peak prod. ratio $(\mathrm{n} / \mathrm{s})$ & $8 \times 10^{13}$ & $5 \times 10^{15}$ & $1 \times 10^{18}$ & $9 \times 10^{14}$ & $2 \times 10^{20}$ & $2 \times 10^{19}$ & $3 \times 10^{17}$ & $1 \times 10^{22}$ & $4 \times 10^{25}$ \\
\hline Peak flux $\left(\mathrm{n} / \mathrm{cm}^{2} / \mathrm{s}\right)$ & $3 \times 10^{19}$ & $9 \times 10^{13}$ & $4 \times 10^{17}$ & $3 \times 10^{16}$ & $7 \times 10^{19}$ & $1 \times 10^{18}$ & $1 \times 10^{21}$ & $1 \times 10^{25}$ & $2 \times 10^{29}$ \\
\hline Laser type & Ti:sapphire & Ti:sapphire & Ti:sapphire & Ti:sapphire & Nd:glass & Nd:glass & Nd:glass & Nd:glass & Nd:glass \\
\hline \multirow[t]{2}{*}{ Reference } & Hah & Kawashima & Zuliek & Komeda & Roth & Pomerantz & Abe & Yamanaka & Hurricane \\
\hline & $2016^{19)}$ & $2015^{22)}$ & $2013^{21)}$ & $2013^{23)}$ & $2013^{29)}$ & $2014^{30)}$ & $2017^{31)}$ & $1986^{32)}$ & $2014^{33)}$ \\
\hline
\end{tabular}

spec.: specification, gen.: generation, ptcl.: particle, blk.: bulk, caps.: capsule, th.: thermal, prod.: produced, ave.: average *Estimated value.

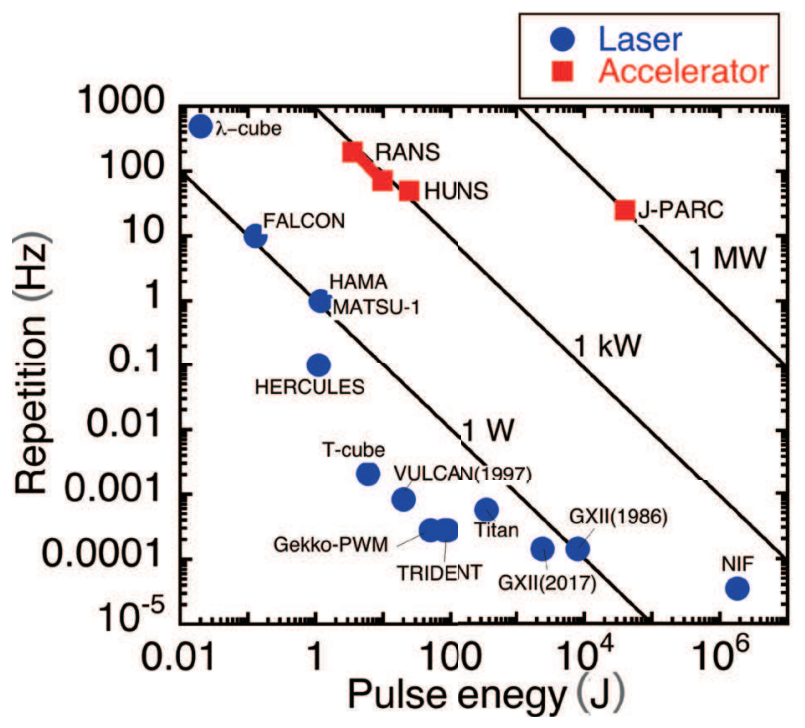

Fig. 3 Repetition rate of neutron source driver in relation to the driving energy.

よるパルス幅がサブピコ秒のTRIDENTレーザーで得ら れた值が，パルスエネルギー当たりの瞬間中性子発生効 率が最も高く, 加速器駆動と同等, $10^{8} \mathrm{n} / \mathrm{sr} / \mathrm{J}$ を達成して いる，そこで，レーザーパルス幅をサブピコ秒に焦点 を当て, フェムト秒への展開も視野にいれて,
$100 \mathrm{~J} / 100 \mathrm{fs} / 100 \mathrm{~Hz}$ 検討スペックの中心に据えた. ピーク出力 $1 \mathrm{PW}$, 平均出力 $10 \mathrm{~kW}$ となる. 中性子源駆動 用高平均出力レーザー装置の実現性検討は, 時田等に よって報告される ${ }^{35)}$ ，レーザー駆動中性子源の研究開発 は発展途上である。したがって，レーザープラズマ専門 家の奮起により，将来，ジュール当たりの瞬間発生効率 が向上されると，レーザーに対する仕様は大幅に緩和さ れる。

中性子発生点におけるパルス当たりの中性子ピークフ ラックスで比較すると, レーザー中性子源の特性が際立 つ. Fig. 4 に，パルス当たりの中性子ピークフラックス を示す. 加速器駆動型のピークフラックスは, Table 1 に示すように加速ビームサイズ (文献值)から算 出した断面積と中性子発生ターゲット厚み (文献值)で囲 まれる空間を中性子発生領域, 加速器ビームパルス幅を 中性子パルス幅として概算した。 J-PARCについては, 通常のダブルバンチ運転 (平均出力 $1 \mathrm{MW}$ ，パルスエネ ルギー $40 \mathrm{~kJ}$, パルス幅 $1 \mu \mathrm{s})$ に加えて, 中性子発生点に おける高ピークフラックスが期待できるシングルバンチ 運転 (平均出力0.5 MW, パルスエネルギー $20 \mathrm{~kJ}$, パルス 幅0.1 $\mu \mathrm{s})^{14)}$ の值も示した. レーザー駆動型の中性子パル ス幅は，文献に表記されていないものは，レーザー駆動 加速イオンがターゲット中を伝搬する時間とした。レー 


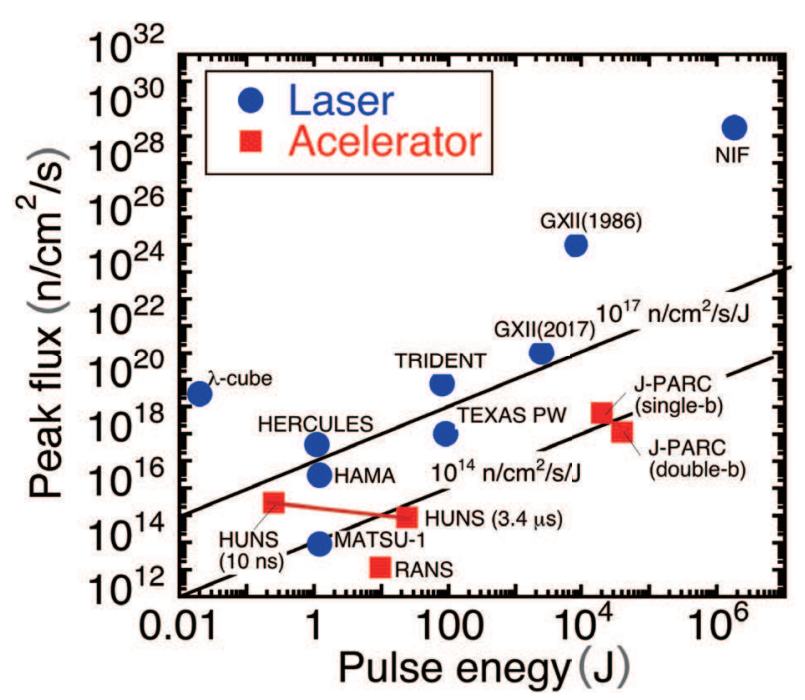

Fig. 4 Neutron luminosity at source in relation to the driver energy.

ザー駆動中性子源のパルス幅については，朝比奈等によ る数值解析がある ${ }^{36)}$. レーザー駆動型は, 加速器駆動型 と比較して，短パルス及び光源サイズが小さい。した がって，単位時間単位面積あたりの中性子輝度で評価す ると，同じドライバーエネルギーにおいて，3桁以上の 輝度を得ることができる。ここで列挙した中性子発生方 式は，フェムト秒及びサブピコ秒レーザーを用いたもの はピッチャーキャッチャー方式によるビーム核融合，ナ ノ秒レーザーを用いたものは爆縮あるいはそれに類似し た方式による熱核融合である。特に，爆縮方式を用いる と, ピークフラックス $10^{29} \mathrm{n} / \mathrm{cm}^{2} / \mathrm{sec}$ を超える性能が期待 できる。

レーザー駆動中性子源の有する高輝度性は, レーザー 駆動特有の性能である。従来の中性子源では, 発生後に 減速材を設け，中性子エネルギーを熱領域まで下げてイ メージングなどに活用されてきた。高輝度中性子源の適 用可能性は検討段階にあるが, 時間分解能ナノ秒以下の 高速現象中性子イメージング或いは中性子回折解析など が原理的に可能であろう。さらに、レーザー光で実現さ れた光と物質の相対論効果のような，照射強度を向上す ることで出現した非線形物理機構が, 中性子においても 存在するのであれば，新たな展開が見いだせるかもしれ ない.レーザー駆動中性子源及びガンマ線源による宇宙 核物理 · 原子力基礎研究への応用が検討されてい $ろ^{37,38)}$.

\section{3.レーザー駆動型中性子源開発に 求められる要素技術}

レーザー駆動型中性子源をシステム開発するために は, 中性子発生までのプロセスにおいて, 以下3つの要 素技術：(1)レーザードライバ，(2)レーザー伝送/集光， (3) ターゲット供給のシステム統合が求められる. 本章 では，レーザー駆動型中性子源のシステム化に求められ る要素技術の現状について紹介する。
3.1 レーザードライバ

レーザードライバ開発に求められることは，高ピーク 出力パルスレーザーの高平均出力化である．Fig. 5 に, パルスレーザーの平均出力に対するピーク出力を示し た。次世代産業用パルスレーザーの市販仕様は, 平均出

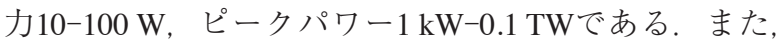
同等の平均出力において, ピークパワーがPWに達する フェムト秒レーザーも理化学用途向けに市販されている (Fig. 5 : 三角). 一方, 平均出力 $100 \mathrm{~W}$ 以上のパルス レーザーは，開発途上にある。

高ピーク出力レーザーの平均出力向上のためには，半 導体励起レーザーの技術開発が求められる。半導体レー ザーをレーザー励起光源として用いることで, 従来のフ ラッシュランプ励起方式と比べ熱負荷が低減され，パル スレーザーの高平均出力が可能となった. Fig. 5 中の四 角に示すのが, これまで開発された半導体励起レーザー である。現在，欧州連合によるELIプロジェクトにおい て, 100 ジュール級半導体励起レーザー開発が進展し た。 英国ラザフォードアップルトン研が開発したレー ザーDiPOLEは, 平均出力 $1 \mathrm{~kW}(100 \mathrm{~J} / 10 \mathrm{~Hz})$ の1時間運 転を達成している ${ }^{39)}$ 。また，米国リバモア研では，平均 出力 $2 \mathrm{~kW}(200 \mathrm{~J} / 10 \mathrm{~Hz})$ を目指した開発がすすめられて おり, 現在 $80 \mathrm{~J} / 3.3 \mathrm{~Hz}$ を達成している。国内において は, 2008 年に, 平均出力 $213 \mathrm{~W}$, ピーク出力 $2.4 \mathrm{GW}$ の HALNAレーザーが開発され，現在，レーザー加工を目 指した500 J超級レーザー開発プロジェクトが進行中で ある ${ }^{41)}$. 国内外において，高平均出力化を目指したレー ザー開発が勢力的に展開されている。大阪大学におけ る10 kW級繰り返し超高強度レーザー開発動向につい て，河仲等により報告される ${ }^{42)}$.

半導体励起レーザーをポンプ光源としたチタンサファ イアレーザーにより, 高ピーク, 高平均出力化が達成可 能である。国内では，ジュール級半導体励起レーザー KURE-1 ${ }^{43)}$ をポンプ光源としたピーク出力 $10 \mathrm{TW}$ 超級チ タンサファイアレーザーHAMA ${ }^{44,45)}$ とMATSU- ${ }^{22)}$ が開発 され，応用に供されている。例えば, Fig. 5 丸で示す HAMAレーザーは, 繰り返しレーザー核融合研究開発 を目的として開発され，連続中性子発生及び核融合研究

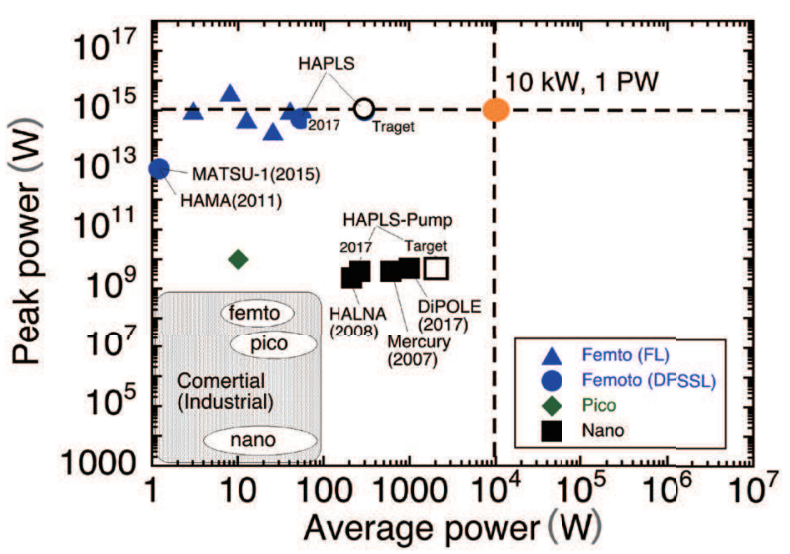

Fig. 5 Pulse laser specification: average power versus pulse peak power. 
に供されている $23,46-48)$. さらに出力 $20 \mathrm{TW}$ 全固体半導 体レーザーMATSU-1は, 重水素化ナノ粒子を用い た2.45 MeV核融合中性子の繰り返し発生(繰り返し $1 \mathrm{~Hz}$, 発生率98\%以上)を達成している。欧州のELIプロジェク トでは, HAPLSレーザーが完成し, 現在, ピーク出 力0.5 PW, 平均出力 $50 \mathrm{~W}(16 \mathrm{~J} / 30 \mathrm{fs} / 3.3 \mathrm{~Hz})$ を達成して いる ${ }^{49)}$. 本方式は, ピーク出力 $1 \mathrm{PW}(100 \mathrm{~J} / 100 \mathrm{fs})$, 平 均出力 $10 \mathrm{~kW}$ 達成するための検討候補の一つである.

\section{2 レーザー伝送/集光}

パルス圧縮回折格子のダメージしきい值, 及び繰り返 し数により，伝送ビームフルエンスが制限される。超高 強度レーザーでは，チャープ増幅パルスを圧縮するた め, 回折格子を用いる。回折格子の表面は, 金コート或 いは誘電体多層膜コートされる。誘電体多層膜コート は，金コートよりもレーザーフルエンスに対する耐力 が5倍以上高い. 中心波長 $1 \mu \mathrm{m}$ 帯のピコ秒レーザーにお いては, 回折格子への誘電体多層膜コート技術が完成し ている. 一方，中心波長 $0.8 \mu \mathrm{m}$ 帯のフェムト秒レーザー では, 開発段階にあり，金コート回折格子が用いられて いる。金コートのダメージしきい值は，パルス幅30 fsに おいて， $0.1 \mathrm{~J} / \mathrm{cm}^{2}$ とされる。ダメージしきい值の $1 / 2 て ゙$ 運 用すると，100 Jフェムト秒レーザーのビーム直径は， 約 $60 \mathrm{~cm}$ となる.レーザー繰返しが数 Hz以上となると, 平均熱負荷などを考慮する必要がある。フェムト秒レー ザーパルスのための高耐力回折格子の研究開発が続けら れている。

繰り返し運用の際は，集光光学系をターゲットデブリ から保護する必要がある。集光強度 $10^{22} \mathrm{~W} / \mathrm{cm}^{2}$ 以上で中 性子発生を目指す際は, F值が1程度の短焦点集光光学 系を用いる。この際，集光光学系は，照射ターゲットと の距離が短くなるため, ターゲットデブリに晒される。 ターゲットデブリの影響は，レーザー繰り返し数が高く なるにつれ，積算される，ターゲットデブリを防ぐ方法 として, ターゲットデブリの生じないターゲットを用い る方法と，デブリシールド導入する 2 つ方法が考えら れる。ターゲットデブリに対して，金属ターゲットを用 いるレーザーEUV光源開発では，その回収対策が試み られている50).

\section{3 ターゲット供給}

レーザー駆動量子ビーム用ターゲット供給の高繰り返 し化(数 Hz以上)が求められる。ターゲット供給技術は, レーザー駆動中性子源を含めたレーザー加速技術全体の 課題として，検討が続けられている。特に，欧州では， 「高繰り返しレーザー駆動ビーム用ターゲット開発 (TRG) 」と題した会議が2013年より隔年で開催されてい る。繰り返し運用が可能なターゲットとして, 従来テー プターゲットが用いられてきた。しかし，一般的なテー プターゲットでは，レーザーエネルギーが上昇すると， レーザー照射後, テープが切断され，供給が停止してし まう。連続供給可能な薄膜ターゲットとして，オハイオ 大では，液体結晶フィルムターゲットが開発された ${ }^{51)}$ 。
これは, 液体結晶の体積と温度を変えることで, フィル ム厚みを $10 \mathrm{~nm}$ から $10 \mu \mathrm{m}$ の間で調整可能である. ショット毎に，液体結晶をワイパーで供給し， $0.1 \mathrm{~Hz}$ の運用が可能である。ささに，才ハイオ大では，常温液 体シートターゲット ${ }^{52}$ が用いられ，500 Hzレーザー実験 に供されている。独では，クライオ液柱ターゲットが開 発された ${ }^{53)}$. SLACでは, クライオ液中水素ターゲット が開発され ${ }^{54)}$ ，不純物のない高速プロトン発生に成功し ている ${ }^{55)}$. ターゲット投入技術は，投入エネルギー以上 の中性子エネルギー発生 (粒子エネルギ $\times$ 発生量) が期 待できる将来の核融合炬においても，必須の技術であ る。繰り返しレーザー技術の進展により，レーザー駆動 中性子源を含む将来のレーザープラズマ応用を視野にい れたターゲット供給技術開発が求められる時代となっ た。

\section{4. まとめ}

コンパクト中性子源として期待される加速器駆動型, レーザー駆動型を比較し、レーザー駆動型の特徵を明ら かにした。更に，レーザー駆動システムの開発で求めら れる3つの要素技術 1.レーザードライバ，2.レーザー伝 送/集光，3.ターゲット供給の開発状況を紹介した。 レーザー駆動中性子源は，加速器駆動とくらべ，短パル ス性 (パルス幅 $1 \mathrm{~ns}$ 以下), 点光源 (光源サイズ数 $\mathrm{mm}$ 以 下)の特徵を有する。結果，他の方式では得られない高 輝度中性子源が可能であり，ピークフラックスは，ドラ イバー入力エネルギーあたり，加速器駆動の3桁以上高 い性能 $\left(10^{17} \mathrm{n} / \mathrm{cm}^{2} / \mathrm{s} / \mathrm{J}\right)$ を有する。一方, 平均出力発生率 を考慮すると， 5 桁以上低く，10 $10^{6} \mathrm{n} / \mathrm{sr} / \mathrm{s}$ に留まる。した がって, レーザードライバ開発に対して, 高ピーク出力 レーザーの高平均出力化が要求される。そのためには, 近年, 国内外で開発が活性化している高出力パルス半導 体励起レーザーの技術開発とその適用が肝心である。

\section{謝 辞}

加速器駆動中性子源の情報を提供頂いた池田 裕二郎 博士，及び大竹 淑恵博士に謝意を表します。

\section{参考文献}

1）北川米喜，森芳孝：レーザー研究 45 (2017) 58

2) 千德 靖彦：レーザー研究 34 (2006) 142.

3) 米田修: 学位論文, 光産業創成大学院大学 (2013) 浜松.

4) 西村博明：レーザー研究 43 (2015) 70.

5) 西内 満美子：プラズマ・核融合学会誌 88 (2012) 5.

6) A. Macchi, M. Borghesi, and M. Passoni: Rev. Mod. Phys. 85 (2013) 751.

7）余語 覚文，花山 良平，安部勇輝，西村博明：レーザー研 究 46 (2018) 582 .

8) J-PARC Center, MLF Division: JAEA-Technology 2011-035 (2012).

9) High-Intensity Proton Accelerator Team: JAEA-Tech 2003-044/ KEK Report 2002-13 (2003) p. 87.

10) 物質・生命科学実験施設建設チーム：JAERI-Tech 2004001vol. 1 (2004) p. 12. 
11) H. Kogawa, S. Ishikura, H. Sato, M. Harada, S. Takatama, M. Futakawa, K. Haga, R. Hino, S. Meigo, F. Maekawa, et al.: J. Nucl. Mat. 343 (2005) 178.

12) H. Takada, K. Haga, M. Teshigawara, T. Aso, S. Meigo, H. Kogawa, T. Naoe, T. Wakui, M. Ooi, M. Harada, and M. Futakawa: Quantum Beam Sci. 1 (2017) 8.

13) 神永 雅紀, 寺田敦彦, 羽賀 勝洋, 木下秀孝, 石倉 修一 日野竜太郎：JAERI-Tech 2000-076 (2001)

14）井頭 政之：核データニュース (2005) 41.

15) Y. Ikeda, A. Taketani, M. Takamura, H. Sunaga, M. Kumagai, Y. Oba, Y. Otake, and H. Suzuki: Nucl. Instrum. Methods A 833 (2016) 61.

16) 鬼柳 善明，木野幸一： Isotope News 717 (2014) 31 .

17) M. Furusaka, H. Sato, T. Kamiyama, M. Ohnuma, and Y. Kiyanagi: Physics Procedia 60 (2014) 167.

18）大学加速器連携協議会：大学加速器施設一覧 (2017).

19) J. Hah, G. M. Petrov, J. A. Nees, Z.-H. He, M. D. Hammig, K. Krushelnick, and A. G. R. Thomas: Appl. Phys. Lett. 109 (2016) 144102 .

20) T. Ditmire, J. Zweiback, V. P. Yanovsky, T. E. Cowan, G. Hays, and K. B. Wharton: Nature 398 (1999) 489.

21) C. Zulick, F. Dollar, V. Chvykov, J. Davis, G. Kalinchenko, A. Maksimchuk, G. M. Petrov, A. Raymond, G. R. Thomas, L. Willingale, et al:: Appl. Phys. Lett. 102 (2013) 124101.

22）川嶋利幸, 渡利威士, 関根尊史, 松門宏治, 西原功修, 高木 勝, 吉村 涼, 幡野 佑真, 竹内 康樹, 佐藤 仲弘 : レー ザー研究 43 (2015) 108 .

23) O. Komeda, Y. Nishimura, Y. Mori, R. Hanayama, K. Ishii, S. Nakayama, Y. Ktagawa, T. Sekine, N. Sato, T. Kurita, et al.: Sci. Reports 3 (2013) 2561

24) P. A. Norreys, A. P. Fews, F. N. Beg, A. R. Bell, A. E. Dangor, P. Lee., M. B. Nelson, H. Schmidt, M. Tatarakis, and M. D. Cable: Plasma Phys. Control. Fusion 40 (1998) 175.

25) N. Izumi, Y. Sentoku, H. Habara, K. Takahashi, F. Ohtani, T. Sonomoto, R. Kodama, T. Norimatsu, H. Fujita,Y. Kitagawa, et al.: Phys. Rev. E 65 (2002) 036413.

26) H. Habara, K. L. Lancaster, S. Karsch, C. D. Murphy, P. A. Norreys, R. G. Evans, M. Borghesi, L. Romagnani, M. Zepf, T. Norimatsu, et al.: Phys. Rev. E 70 (2004) 046414.

27) D. P. Higginson, J. M. McNaney, D. C. Swift, T. Bartal, D. S. Hey, R. Kodama, S. Le Pape, A. Mackinnon, D. Mariscal, H. Nakamura, et al.: Phys. Plasmas 17 (2010) 100701.

28) L. Willingale, G. M. Petrov, A. Maksimchuk, J. Davis, R. R. Freeman, A. S. Joglekar, T. Matsuoka, C. D. Murphy, V. M. Ovchinnikov, A. G. R. Thomas, et al.: Phys. Plasmas 18 (2011) 083106.

29) M. Roth, D. Jung, K. Falk, N. Guler, O. Deppert, M. Devlin, A. Favalli, J. Fernandez, D. Gautier, M. Geissel, et al.: Phys. Rev. Lett. 110 (2013) 044802.

30) I. Pomerantz, E. McCary, A. R. Meadows, A. Arefiev, A. C. Bernstein, C. Chester, J. Cortez, M. E. Donovan, G. Dyer, E. W. Gaul, et al. : Phys. Rev. Lett. 113 (2014) 184801.

31) Y. Abe, A. Sunahara, S. Lee, T. Yanagawa, Z. Zhang, Y. Arikawa, A. Morace, T. Nagai, T. Ikenouchi, S. Tokita, et al.: Appl. Phys. Lett. 111 (2017) 233506.

32) C. Yamanaka, S. Nakai, T. Yabe, H. Nishimura, S. Uchida, Y. Izawa, T. Norimatsu, N. Miyanaga, H. Azechi, M. Nakai, et al.: Phys. Rev. Lett. 56 (1986) 1575.

33) O. A. Hurricane, D. A. Callahan, D. T. Casey, E. L. Dewald, T. R. Dittrich, T. Döppner, M A. Barrios Garcia, E. E. Hinkel, L. F. Berzak Hopkins, P. Kervin, et al.: Phys. Plasmas 21 (2014) 056314.
34) S. Le Pape, L. F. Berzak Hopkins, L. Divol, A. Pak, E. L. Dewald, S. Bhandarkar, L. R. Bennedetti, T. Bunn, J. Biener, J. Crippen, et al:: Phys. Rev. Lett. 120 (2018) 245003.

35) 時田茂樹, 森芳孝, 森 道昭, 河仲準二：レーザー研究 46 (2018) 571.

36）朝比奈隆志, 田中 浩基, 安部勇輝, 森芳孝, 余語 覚文, 長友 英夫, 花山 良平, 早川岳人：レーザー研究 46 (2018) 594.

37) L. A. Bernstein, D. L. Bleuel, J. A. Caggiano, C. Cerjan, R. J. Fortner, J. Gostic, P. M. Grant, N. Gharibyan, C. Hagmannm, R. Hatarik, et al.: Plasma Fus. Res. 9 (2014) 4404101.

38) T. Hayakawa, T. Nakamura, H. Kotaki, M. Kando, and T. Kajino: Quantum Beam Sci. 1 (2017) 3.

39) P. Mason, M. Divoký, K. Ertel, J. Pilař, T. Butcher, M. Hanuš, S. Banerjee, J. Phillips, J. Smith, M. De Vido, et al.: Optica 4 (2017) 438.

40) R. Yasuhara, T. Kawashima, T. Sekine, T. Kurita, T. Ikegawa, O. Matsumoto, M. Miyanaga, H. Kan, H. Yoshida, J. Kawanaka, et al.: Opt. Lett. 33 (2008) 1711.

41）川嶋利幸, 栗田 隆史, 関根 尊史, 渡利威士, 竹内 康樹, 水田 好雄, 倉田 将輝, 森田 宇亮, 玉置 善紀, 加藤 義則, 他：レーザー研究 45 (2017) 560.

42) 河仲準二, 時田茂樹, 椿本 幸治, 吉田 英次, 郭 晓杨, 李朝阳, 藤岡加奈, 森尾登, 荻野純平, 本越伸二他： レーザー研究 46 (2018) 576

$43)$ T. Sekine, H. Sakai, Y. Takeuchi, Y. Hatano, T. Kawashima, H. Kan, J. Kawanaka, N. Miyanaga, and T. Norimatsu: Opt. Express 21 (2013) 8393.

44) Y. Mori, T. Sekine, O. Komeda, S. Nakayama, K. Ishii, R. Hanayama, K. Fujita, S. Okihara, N. Satoh, T. Kurita, et al.: Nucl. Fusion 53 (2013) 073011

45）森芳孝, 関根 尊史, 米田修, 西村靖彦, 三浦 永祐, 中山 師生, 石井勝弘, 花山 良平, 佐藤 仲弘, 栗田 隆史, 他： レーザー研究 42 (2014) 154.

46) Y. Kitagawa, Y. Mori, R. Hanayama, S. Okihara, K. Fujita, K. Ishii, T. Kawashima, N. Sato, T. Sekine, R. Yasuhara, et al.: Plasma Fusion Res. 6 (2011) 1306006.

47) Y. Kitagawa, Y. Mori, O. Komeda, K. Ishii, R. Hanayama, K. Fujita, S. Okihara, T. Sekine, N. Satoh, T. Kurita, et al.: Phys. Rev. Lett. 108 (2012) 155001.

48) Y. Mori, Y. Nishimura, R. Hanaayma, S. Nakayama, K. Ishii, Y. Kitagawa, T. Sekine, N. Sato, T. Kurita, T. Kawashima, et al.: Phys. Rev. Lett. 117 (2016) 055001.

49) E. Sistrunk, T. Spinka, A. Bayramian, S. Betts, R. Bopp, S. Buck, K. Charron, J. Cupal, R. Deri, M. Drouin, et al.: Conference on Lasers and Electro-Optics (OSA, 2017) STh1L.2.

50) 東口武史, 藤岡 慎介, 砂原 淳, 柳田 達哉, 溝口 計：レー ザー研 究 42 (2014) 14.

51) P. L. Poolea, C. D. Andereck, D. W. Schumacher, R. L. Daskalova, S. Feister, K. M. George, C. Willis, K. U. Akli, and E. A. Chowdhury: Phys. Plasmas 22 (2014) 039905.

52) J. T. Morrison, E. A. Chowdhury, K. D. Frische, S. Feister, V. M. Ovchinnikov, J. A. Nees, C. Orban, R. R. Freeman, and W. M. Roquemore: Phys. Plasmas 22 (2015) 043101.

53) R. A. Costa Fraga, A. Kalinin, M. Kuühnel, D. C. Hochhaus, A. Schottelius, J. Polz, M. C. Kaluza, P. Neumayer, and R. E. Grisenti: Rev. Sci. Instrum. 83 (2012) 025102.

54) J. B. Kim, S. Göde, and S. H. Glenzer: Rev. Sci. Instrum. 87 (2016) 11E328.

55) S. Göde, C. Rödel, K. Zeil, R. Mishra, M. Gauthier, F.-E. Brack, T. Kluge, M. J. MacDonald, J. Metzkes, L. Obst, et al.: Phys. Rev. Lett. 118 (2017) 194801. 